\title{
CHALLENGES AND OPPORTUNITIES OF INFORMATION AND COMMUNICATION TECHNOLOGIES FOR DISSEMINATION OF AGRICULTURAL INFORMATION IN ETHIOPIA
}

\author{
Abebaw A. Getahun \\ Department of agricultural economics, Raya University, Ethiopia.
}

\section{ART ICLE INFO}

\section{Article history}

Received: November 11, 2019

Revised: February 27, 2020

Accepted: April 25, 2020

\section{Keywords}

Agriculture

Challenges

Ethiopia

ICTs $4 \mathrm{Ag}$

Information

Opportunities
A B S T R A C T

This review paper analyses the challenge and opportunities of information and communication technologies for dissemination of agricultural information in Ethiopia. Understanding the challenges and opportunities of information and communication technologies enables to solve the problem of information problem to smallholder farmers. The data was collected, assessed and reviewed from recent secondary data sources from Central statistical agency, and scholarly articles published on the issue of information and communication technology in agriculture (ICT $4 \mathrm{Ag}$ ).Compared to the other sector like governance, health and education sectors, ICT-adoption in the agricultural sector has started relatively late in Ethiopia. Even though it is in infant stage, there are many agricultural ICT related service and application in Ethiopia. The current radical penetration of ICTs like mobile phone, website, social media and other internet/online services brings an immense prospect to farmers to create, share, store, process, interpret and preserve agricultural information and knowledge. ICT related agricultural extension system is the solely choice for dissemination of agricultural knowledge and information. Ethiopia is the country which has more than 65000 extension personnel for agricultural extension. But this extension system is not sustainable since it is very costly and inefficient. Thus, agricultural extension policy and intervention should focus on ICT based extension system.

Corresponding Author: Abebaw A. Getahun

Email: abebawabebe2018@gmail.com

(C) The Author(s) 2020.

\section{INTRODUCTION}

Improving the livelihood of smallholder farmers through a productive agriculture play an imperative role in reducing poverty and serve as an important engine for growth in developing countries. Over 475 million smallholder farmers are the foundation of agricultural and food supply chains in most developing countries (FAO, 2012). Nearly 80\%of the food supply in Asia and Sub-Saharan Africa is produced by smallholder farmers (World Bank, 2017). Agriculture in Ethiopia accounts about $50 \%$ of the GDP employs $80 \%$ of the labor force and contributes $85 \%$ of the total export earnings (EEO, 2017). In Ethiopia, agriculture is subsistence and dominated by about 11.7 million smallholders cultivating $95 \%$ of the national agricultural production (Gebrerufael, 2017). Agricultural practices adopted by smallholder farmers in Ethiopia and else in developing countries are not perceived economically viable and sustainable pertaining to inadequate access to information on new agricultural technology, market information problem, inadequate climate information and weak links across the agricultural value chains 
(Abebe and Mammo Cherinet, 2018). Smallholder farmers need access to timely and comprehensive information on production, value addition and markets. Agricultural information is a critical ingredient to improving small-scale agricultural production and linking farmers to markets. This consequently leads to improved rural livelihoods, food security and national growth (Amos, 2013). Ethiopia has adopting public agricultural extension which system is very costly to. The county has more than 65000 extension personnel for agricultural extension, this made the countries 3rd and 1st in Africa.

Information Communication Technologies (ICTs) is one important mechanism and offer a great opportunity to solve the problem of information problem to smallholder farmers. More households in developing countries own a mobile phone than have access to electricity or clean water, and nearly $70 \%$ of the bottom fifth of the population in developing countries own a mobile phone. The number of internet users has more than tripled in a decade from 1 billion in 2005 to an estimated 3.2 billion at the end of 2015 (World Bank, 2017). Especially this newly ICT tool (mobile phone) brings an enormous prospect to disseminate agricultural information through SMS, IVR (Interactive voice response), internet, radio through mobile phone. ICTs can facilities exchange of information among farmers from diverse social groups, allow rapid access to information needed for exchanging, buying, producing, and selling products and lead to increased productivity gains (Langat et al., 2016).

The objective of this paper is to assess the role, the challenges and opportunity of ICTs use for dissemination of agricultural information in Ethiopia. This paper focuses on meaning and role of ICT in agriculture (ICT4Ag or e- agriculture), the contribution of ICTs for agriculture in Ethiopia during different agricultural season, the challenges and opportunities of ICT use in Ethiopia and summarizes the main findings of the review and draws appropriate conclusions. The data that are collected, assessed and reviewed from secondary data sources from Central statistical agency, empirical study, country profile, different authors and researchers have written on the issue of information and communication technology services and application profiles for agriculture (ICT $4 \mathrm{Ag}$ ).

\section{Meaning and Role of ICT for Agriculture (ICT4Ag or e- agriculture)}

ICTs is defined differently depending on its type and nature. According to Ritchie and Brindley (2005), ICTs are the array of primarily digital technologies designed to collect, organize, analyses, store, process and communicate information. As a broad concept ICT includes; information systems, information technology and digitization. ICT can be categorized into old that include telephones, radio, television, films, audio and video cassettes and new ICT that include, computers, mobile phones, faxes, point of sale systems, global positioning systems, informational geographical systems, satellites, networked environments and internet (Lashgarara et al., 2011).

ICT $4 \mathrm{Ag}$ is the use of information and communication technologies for agriculture sector. Compared to the other sector like governance, health and education sectors, ICT-adoption in the agricultural sector has started relatively late. This is the reason due to the perception by ICT4D-actors of agriculture as a difficult environment (poor infrastructure, remoteness, poor education etc.), and to the fact that agriculture in developing countries has received relatively little attention from the international (SNRD, 2018). All over the world, ICTs have become increasingly important in all aspects of our daily life and work. There are many ICT tools used in ICT 4 Ag. For instance, M-Agriculture which is the more resent term used to describe the various mobile technologies-based services, which are used in the agriculture sector. Several m services have already been developed that deliver information to farmers either on demand or by sending updates via SMS, interactive voice response or audio recordings. Mservices may also serve to facilitate farmer-to farmer or farmer-to-buyer relations, such as sharing of experiences on farming practices and market information related to prices, supply and demand (Baumüller, 2016). The role of ICTs in agriculture can be dissemination of agricultural market information, agricultural production and extension information like (information related to land preparation, planting, technology usage and other activates up to harvesting) and it can be also climate information. ICTs play a pivotal role in dissemination of market information to farmers that improve their market bargain power, seize market opportunities, to enable valuable marketing decision, better allocation of production factors and 
also to use the information to make choices about marketing (Asenso-Okyere, 2012).

In many Africa countries there is use of ICT in dissemination of market information through different e- application and services. For instance, in Kenya FIT supports the development of a commercially sustainable ICT led interactive media framework that targets and responds to business and market access issues of smallholder farmers among Kenya's rural farming communities. The other instance is the Ethiopia Commodity Exchange (ECX)provides rural based market information tickers, mobile phone Short Messaging Service (SMS), Interactive Voice Response (IVR) service, mass media (TV, radio, and newspaper) and website (www.ecx.com.et). Esoko in Ghana is a private market information service offers a range of mobile and web applications for collecting and sending out agricultural market information using simple text messages. The Esoko platform can be used by individual farmers, agri-businesses and organizations in agricultural value chains. Esoko's tools enable farmers to negotiate better prices, choose different markets. Now it operates in more than 15 sub-Saharan African countries using a variety of business models. One approach it has used is to add complementary services for large buyers (or large farmers that also are buyers) (World Bank, 2010). ICTs can also disseminate agricultural production and extension information in addition to market information. There are number of ICT-based initiatives which cater for non-market information and used for extension services including financial, utilization of best agriculture practices, research, weather, climate, and distribution and supply chain management. Some of the initiatives in different countries include: KenCall Farmers Helpline, Kilimo Salama, MPESA, and Mali Shambani - all in Kenya, Esoko, Coco alink and Radio Ada in Ghana, and MAKWACHA in Malawi that provide agricultural information, advice and support to smallholder farmers over the phone, using voice and voice call-back to farmers (Payne, 2010). Table 1 indicates that different eagriculture applications and services in different countries. sub-Saharan Africa (SSA) the use of unsustainable farming practices, such as excessive soil tillage with no soil covers, have led to a decrease in soil fertility, accelerated erosion, and degradation of arable land. This resulted in decreased yields and food insecurity (Hobbs, 2007; Nkala, 2011). Traditional cultivation practices adopted by smallholder farmers in southern Africa have become less sustainable with increasing population growth and escalating food demand. In Mozambique, around $68 \%$ of the population live in rural areas and are smallholder farmers. Agriculture is the main driver of the country's economy (World Bank, 2006) (Mucavele, 2009), although only 15.7\% of the arable land is cultivated (Filipe and Kring, 2011). Since the agricultural sector in Mozambique is characterized by small farm sizes and soil degradation, conservation agriculture (CA) is advocated as a viable production system which can assist smallholder farmers to increase the sustainability and productivity of crop production practices and ultimately cope with food insecurity.

The promotion of CA practices in southern Africa started many decades ago. Thus, overall aims were reducing soil degradation, increasing crop yield, minimizing the risk of crop failure, and thereby increasing food insecurity. In general, CA is based on three principles namely: 1) minimal soil disturbance, 2) maintaining a permanent soil cover using at least $30 \%$ of crop residues (Berger et al., 2008; Muchinapaya, 2012) and 3) crop rotation or intercropping (Giller et al., 2009; Thierfelder et al., 2013). Conservation agriculture, therefore, aims to improve the use of agricultural resources through the combined management of soil, water, and biological resources. Despite the benefits and continued efforts by national and international organizations to promote the adoption of CA practices in Sub Sahara Africa, the adoption rate among smallholder farmers is still very low. 
Table 1. Common E-agriculture (ICTs 4Ag) services in Ethiopia and other Africa countries.

\begin{tabular}{|c|c|c|}
\hline $\begin{array}{l}\text { e-agriculture } \\
\text { Application/service name }\end{array}$ & Country & Its contribution and description \\
\hline mLouma & Senegal & $\begin{array}{l}\text { mLouma is a web and mobile service which connects } \\
\text { farmers to food purchasers by displaying real time market } \\
\text { prices and localizations. The solution is based on Web, } \\
\text { SMS and other applications. }\end{array}$ \\
\hline NAFIS & Kenya & $\begin{array}{l}\text { It is the national Farmers Information Service (NAFIS) } \\
\text { that Kenya Farmers can receive and exchange timely news } \\
\text { and information on agriculture, weather patterns and } \\
\text { related issues via their mobile phones. }\end{array}$ \\
\hline ICT4Dev.ci & Ivory Coast & $\begin{array}{l}\text { ICT4Dev.ci is an ICT based service dedicated to } \\
\text { agriculture, focusing on young farmers. }\end{array}$ \\
\hline $\begin{array}{l}\text { Zambia National } \\
\text { Farmer Union (ZNFU) }\end{array}$ & Zambia & $\begin{array}{l}\text { Menu based mobile platform (USSD) with extension } \\
\text { advice, market prices, weather info and agric stakeholder } \\
\text { contact. }\end{array}$ \\
\hline Esoko & $\begin{array}{lr}\text { Kenya, Malawi, } & \text { Rwanda, } \\
\text { Ghana, } & \text { Nigeria, } \\
\text { Cameroon, } & \text { Benin, } \\
\text { Burkina } & \end{array}$ & $\begin{array}{l}\text { Esoko is one of the oldest private companies proposing its' } \\
\text { technologically advanced platforms and services related to } \\
\text { markets, trade and prices to an increasing range of } \\
\text { countries in Africa. }\end{array}$ \\
\hline (LINKS) & Tanzania, Kenya, Ethiopia & $\begin{array}{l}\text { Livestock Information Network Knowledge System } \\
\text { (LINKS): Provide Livestock prices and volumes are } \\
\text { collected through interviews with traders during the peak } \\
\text { of a market day. }\end{array}$ \\
\hline ECX & Ethiopia & $\begin{array}{l}\text { It is the Ethiopia commodity exchange that deliver market } \\
\text { information through mobile phone, radio, television and } \\
\text { website(www.ecx.com.et) }\end{array}$ \\
\hline 8028 hotline service & Ethiopia & $\begin{array}{l}\text { Automated and voice-recorded information on pre- } \\
\text { planting, planting, crop protection, post-harvest, fertilizer } \\
\text { application, processing, and irrigation is accessible to } \\
\text { callers through } 90 \text { service lines }\end{array}$ \\
\hline IPMS & Ethiopia & $\begin{array}{l}\text { Improving Productivity and Market Success (IPMAS): it } \\
\text { provides information from diverse national and } \\
\text { international sources like technology, market related as } \\
\text { well as extension packages for a wide range of crops, } \\
\text { forest products, and livestock related information. }\end{array}$ \\
\hline
\end{tabular}

The Contribution of ICTs for Dissemination of Agricultural Information in Ethiopia

Ethiopia has been adapting public agricultural extension system and it is the largest agricultural extension system in Sub-Saharan Africa, and third largest in the world after China and India (Swanson and Rajalahti, 2010). A total of 8,500 farmers training centers have been established and 63,000 field extension workers (known as development agents-DAs) have been trained. Its services include transferring knowledge to farmers, advising and educating farmers in their decision making, enabling farmers to clarify their own goals and possibilities, and stimulating desirable agricultural developments. However, from this extension service it couldn't get fruitful result due to high cost, labor inefficiency, relevancy and time (Davis et al., 2010; Tegegn et al., 2017).

In order to overcome the problem of former extension system and to increase the extension systems in geographic scope and scale, as well as to facilitate more 
frequent, relevance and timely communications between extension agents, researcher and farmers, ICTs mainly both traditional ICTs (radio, television, video cassettes and modern ICTs (mobile phone, internet, website) are offer a great opportunity. ICTs in Ethiopia can enable revolutionizing traditional agricultural extension services by providing smallholder farmers with direct access to "best practice" agronomic advice (Wondirad, 2015). The following are ICT based application system used to deliver agricultural production information, market information and climate information between farmers, extension workers, researchers and other agricultural development partners.

\section{The 8028 Hotline Information Service Initiative in Ethiopia}

This hotline service is started by the Agricultural Transformation Agency (ATA) collaboration with Ethiopia Ministry of Agriculture, Ethiopia Telecommunication and Ethiopian Institute of Agricultural Research (EIAR). Farmers can access automated and voice-recorded information related to pre-planting, planting, crop protection, post-harvest, fertilizer application, processing, and irrigation by simply dial to 8028 in local language. Twelve weeks after its launch in the Oromia, Amhara, Tigray and SNNP regions, the hotline received nearly 1.5 million calls from 300000 farmers. There were more than 90 lines taking an average of 35,000 calls a day.

Within 6 months of its launch, the system handled approximately 3 million phone calls from over 500,000 registered callers. On the average, the system received 176,431 new and 879,573 return calls in a month. Of the total number of callers, $86 \%$ were farmers, $5 \%$ were development agents and $2.2 \%$ were agricultural experts. Women made up $19 \%$ of total callers. The service was available in three of Ethiopia's main languages: Amharic, Oromiffa and Tigringa. The responsible agency, ATA, worked closely with the gate's foundation, the Netherlands embassy in Ethiopia and Canada's department of foreign affairs, trade and development (ATA, 2014; Tegegn et al., 2017).

\section{The Ethiopia Commodity Exchange (ECX)}

The ECX market data strategy involves harnessing the power of modern information and communication technologies to empower all market actors, including smallholder farmers to access markets more efficiently and profitably. The key market dissemination channels at ECX are rural based market information tickers, mobile phone Short Messaging Service (SMS), Interactive Voice Response (IVR) service, mass media (TV, radio, and newspaper) and website (www.ecx.com.et). SMS is text messages sent and received with mobile phones. The Interactive Voice Response (IVR) system is fully automated telephonebased systems that allow stakeholders to access price information 24 hours a day, 7 days a week. ECX is disseminating market information on daily basis via radio, television and newspaper. TV transmitting ECX market updates three times a day (noon, afternoon and evening). Radio (national radio stations, FM Addis and regional FM radio stations) are transmitting ECX market updates four times a day (morning, noon, afternoon, and evening). ECX, on average, about more than 20,000 calls are made daily via a toll-free number seeking for price information (Tadesse, 2010). The data given in Table 2 is the illustration of different e-agriculture applications and services in Ethiopia.

\section{Opportunities of ICT Use for Agriculture in Ethiopia}

In Ethiopia, mobile phone penetration is growing at a considerable rate. According to the Ministry of Ethiopia Telecommunication Corporation (2015), the overall mobile subscriber grew from 207,000 subscribers in 2004 to approximately 50 million subscribers in 2015 and targets to boost mobile network access to 113 million in the second growth and transformation plan. These growth figures are remarkably high and point to the value that mobile telecommunications presumably bring in the development processes. About $90 \%$ of the country is covered by radio signal and more than 50 percent of the households have access to radios in Ethiopia (Adam, 2010). This coverage of ICTs and ICT related infrastructures has offered a great opportunity to disseminate agricultural information.

Ethiopia has some ICT related opportunities that can be utilized in the dissemination of agricultural knowledge and information to the users. The most notable opportunity is the presence of ICT infrastructure called the woredanet that can be easily extended to reach most of the rural farmers and to further strengthen the research-extension-farmer linkage. At present, almost all woredas have the infrastructure that enabled them to be connected to the network and have access to internet, telecommunication, video conference and databases at national level. In addition, more than half of the kebeles 
in the country were linked to the network by the time of the assessment by Adam (2010). Thus, the presence of such modern ICT initiatives can be considered to be a good opportunity to enhance the flow of agricultural knowledge and information in the country.

Table 2. Types of agricultural information e-agriculture service and its forms in Ethiopia.

\begin{tabular}{|c|c|c|c|}
\hline $\begin{array}{l}\text { Types of } \\
\text { agricultural information }\end{array}$ & ICT based service & Forms of ICT $4 \mathrm{Ag}$ & $\begin{array}{l}\text { Area of delivering } \\
\text { information }\end{array}$ \\
\hline Crop production information & 8028 hotline & $\begin{array}{l}\text { - } \text { Mobile phone (dial 8028) } \\
\text { - Radio (national \&regional } \\
\text { radio) } \\
\text { - SMS }\end{array}$ & $\begin{array}{l}\text { - Land preparation } \\
\text { - Technology use } \\
\text { - Cultivation method } \\
\text { - Irrigation } \\
\text { - Generally, from pre } \\
\text { planting until } \\
\text { harvesting }\end{array}$ \\
\hline Crop marketing information & $\begin{array}{l}\text { ECX (Ethiopia } \\
\text { commodity } \\
\text { exchange) }\end{array}$ & $\begin{array}{l}\text { - Mobile phone (SMS, IVR) } \\
\text { - Media (radio and television } \\
\text { - Website } \\
\text { - www.ecx.com.et }\end{array}$ & $\begin{array}{l}\text { - Crop marketing } \\
\text { information }\end{array}$ \\
\hline Livestock market information & $\begin{array}{l}\text { The Ethiopian } \\
\text { Livestock Market } \\
\text { Information } \\
\text { System (ETLMIS) }\end{array}$ & $\begin{array}{l}\text { - SMS } \\
\text { - Email } \\
\text { - Internet }\end{array}$ & $\begin{array}{l}\text { - Livestock market } \\
\text { information }\end{array}$ \\
\hline
\end{tabular}

Source: Wondirad, 2015; ECX, 2016; Mulugeta \& Akalu, 2017; Abebaw \& Yared, 2018.

Furthermore, radio transmission covers over 90 percent of the country and about half of the Ethiopian households own a radio. This makes radio programs one of the most cost-effective channels for conveying agricultural knowledge and information to the rural community. According to Minten et al. (2014), almost all rural agricultural wholesale markets had access to mobile phones. With the expansion of rural electrification like solar system many farmers have got access to mobile telephone services in recent periods although the network coverage is still very poor (Abebe and Mammo Cherinet, 2018). These bring good opportunity for improving farmer production practices and enhance access to market. Furthermore, the presence of installed e-agriculture service like ECX, 8028 hotline, IPMS and ETLMIS brings a prospect to disseminate agricultural information.

\section{Challenges of use of ICTs for agriculture in Ethiopia}

According to UNDP (2012), the challenges of access to ICT can be divided into two: access to ICT infrastructure and access to ICT services. Access to ICT infrastructure in Ethiopia is still very low despite some noticeable improvements registered in recent years. Electricity infrastructure coverage in the rural parts of the country remains low despite recent efforts to extend the electricity grid to rural areas through the rural electrification program. The low level of electricity coverage has in turn inhibited the expansion of ICT services to rural areas. A study conducted by Tadesse (2010) about effectiveness of the ECX system in connecting the farmers to the market, explained that with the exception of radio, the media of market information being used by ECX are dependent on availability of electric power. On the other hand, the majority of Ethiopian farmers are residents of the rural areas where access to the electric power is rather insufficient or completely unavailable.

Access to ICT infrastructure must be accompanied by access to ICT services. In this regard, the other challenge is how to make ICT services both affordable and available in modes that are convenient to smallholder farmers. These services are not adequately available and accessible to farmers in Ethiopia. Majority of the population lives in rural areas which are characterized by poor availability of telecom and electricity 
infrastructure. Due to this fact, implementing ICT based systems in the villages of rural Ethiopia is very difficult (Mesay, 2007). Ethio telecom (2015) mobile and broadband market insights, statistics and analysis. Ethiopia is one of the last countries in Africa allowing its national telecom a monopoly on all telecom services including fixed, mobile, internet and data communications. This monopolistic control has stifled innovation and retarded expansion. The following are the major problems of ICTs use in agriculture in Ethiopia.

\section{Language Barrier}

Most of farmers in Ethiopia are illiterate and they can't understand and read English language. Since the menu of most mobile phone settings are in English language, farmers are often facing to read and understand mobile SMS and challenging even for calling.

\section{Lack of Farmer's Awareness and Knowledge of ICT}

ICT literacy is still very low and almost nothing for the farmers. What concerned us the most is that ICT literacy even among extension workers are also low, especially those that live in the perimeters or remote areas. Here public awareness campaign through various media is absent. The problem is that many ICT literacy and information technology programs are still in the infant stage (UNESCO, 2014).

\section{Lack of Initiatives from the Government}

Government didn't give concern ICT related infrastructure in rural area. The modern facilities that are available in city places are not been available in remote areas (Tegegn et al., 2017). The farmers who are living in the remote areas are still in the dark. They are deprived from all facilities what they should get. And because of that they are not been able to implement the latest technological aspect in their farming process. Actually, agriculture does not lack resources; it lacks policy and ICT application (Yared, 2015).

\section{CONCLUSION AND RECOMMENDATIONS}

ICT penetration rate has increasing globally in general and in Ethiopia in particular at alarming rate. This offers an enormous opportunity for sharing and disseminating agricultural information between farmers, extension agents, researchers and any other agricultural development partners. Even though ICT $4 \mathrm{Ag}$ is new and in infant stage for the sector relatively to other sectors like government, education and health, now days it is using through different ICT service. Especially, the increasing rate of mobile subscription rate enables to raise m-agriculture application through SMS, IVR, internet, and mobile radio in smallholder farmers.

The Ethiopia Commodity Exchange (ECX), 8028 hotline, the Ethiopian Livestock Market Information System (ETLMIS) and Improving Productivity and Market Success (IPMS) are the major ICT based information service installed for disseminating agricultural information in Ethiopia. Ethiopia has many ICT related opportunities such as wide coverage of mobile network, radio station wave and rural electrification (like solar and wind power) are some of opportunity in using ICT for agriculture. Though the country has the above ICT related opportunities, there are many challenges too which hinder in using ICTs $4 \mathrm{Ag}$. Lacks of initiatives from the government, poor ICT literacy, language barrier and poor ICT related infrastructure in rural area are some of the major factor that affect ICT use $4 \mathrm{Ag}$.

Countries like Ethiopia where public agricultural extension system is very costly to run; ICT related agricultural extension system is the solely choice for dissemination of agricultural knowledge and information. Ethiopia is the country which has more than 65000 extension personnel for agricultural extension, this made the countries 3rd and 1st in Africa. But this extension system is not sustainable since it is very costly, less effective and efficient unless ICT related extension system is adopted. Based on the findings the following recommendations are made;

- Rapid developments in technology infrastructure such as electricity, network coverage, solar power system and other technology that are vital for the improvement of ICTs have to be designed.

- Governments' communications departments can also work hand in hand with agricultural departments and allocate costs, provide effective service and invest in ICT to bridge the technology gap.

- ICT literacy focus on proving awareness creation, basic operation and usage skills to the farmers is very essential. Therefore, woreda agricultural office, communication office and DAs should give trainings and orientation to farmers particularly on how to get market information from the ICT sources such as media, ECX, 8028 service. 


\section{REFERENCES}

Abebe, A., Mammo Cherinet, Y., 2018. Factors Affecting the Use of Information and Communication Technologies for Cereal Marketing in Ethiopia. Journal of Agricultural \& Food Information 20, 5970.

Adam, L., 2010. Ethiopia ICT sector performance review, 2009/2010. Towards Evidence-based ICT Policy and Regulation Policy Paper Series 2.

Amos, W., 2013. Awareness and use of Kenya Agricultural Commodity Exchange Services (KACE) by smallholder farmers of Bungoma. University Nairobi, Kenya.

Asenso-Okyere, K., 2012. Risk and Social Change in an African Rural Economy: Livelihoods in Pastoral Communities. American Journal of Agricultural Economics 94, 1240-1243.

ATA, 2014. 8028 New information service revolutionizes agricultural extension in Ethiopia. Ethiopian Agricultural Transformation Agency, Addis Ababa, Ethiopia.

Baumüller, H., 2016. Agricultural Service Delivery Through Mobile Phones: Local Innovation and Technological Opportunities in Kenya, Technological and Institutional Innovations for Marginalized Smallholders in Agricultural Development. Springer International Publishing, pp. 143-162.

Berger, A., Fredrich, T., Kienzle, J., 2008. Soil Plant Growth and Production Conservation Agriculture Encyclopedia of Life Support Systems, Rome, Italy, p. 115.

Davis, K., Swanson, B., Amudavi, D., Mekonnen, D.A., Flohrs, A., Riese, J., Lamb, C., Zerfu, E., 2010. Indepth assessment of the public agricultural extension system of Ethiopia and recommendations for improvement. International Food Policy Research Institute (IFPRI) Discussion Paper 1041.

EEO, 2017. Overview of Ethiopia economic environment and key sector report, Ethiopia Economic Outlook. African Development Bank, Ethiopia.

FAO, 2012. Tropical and Horticultural Products Service, Commodities and Trade Division (ESC). Food and Agriculture Organization of the United Nations, Rome.

Filipe, M., Kring, T., 2011. Agriculture and poverty reduction in Mozambique, Economic and policy analysis unit Brief. United Nation Development Programme, New York.

Gebrerufael, G., 2017. Smallholder Subsistence Agriculture: Why Ethiopia is Still Here? American Research Journal of Agriculture 1, 1-12.

Giller, K.E., Witter, E., Corbeels, M., Tittonell, P., 2009. Conservation agriculture and smallholder farming in Africa: the heretics' view. Field Crops Research 114, 23-34.

Hobbs, P.R., 2007. Conservation agriculture: What is it, and why is it important for future sustainable food production? Journal of Agricultural Science 145, 127-137.

Langat, R.J., Litondo, K.O., Ntale, J.F., 2016. Information communication technologies and marketing decisions among small scale farmers in Kenya: Review of Evidence. International Journal of Economics, Commerce and Management 4, 11671180.

Lashgarara, F., Mohammadi, R., Najafabadi, M.O., 2011. Identifying appropriate information and communication technology (ICT) in improving marketing of agricultural products in Garmsar City, Iran. African Journal of Biotechnology 10, 11537-11540.

Mesay, Z., 2007. Market Information System and the Ethiopia commodity exchange. Addis Ababa University, Ethiopia.

Minten, B., Stifel, D., Tamru, S., 2014. Structural Transformation of Cereal Markets in Ethiopia. The Journal of Development Studies 50, 611-629.

Mucavele, F.G., 2009. True Contribution of Agriculture to the Economic Development of Mozambique. Food, Agriculture, and Natural Resources Policy Analysis Network (FANRPAN).

Muchinapaya, T., 2012. The sustainability of conservation farming in the smallholder farming sector: a case of Guruve communal area in Zimbabwe, Department of Agricultural Economics and Extension

University of Zimbabwe, Zimbabwe.

Nkala, P., 2011. Assessing the impacts of conservation agriculture on farmer livelihoods in three selected communities in central Mozambique. Universität für Bodenkultur Wien (BOKU), Mozambique, Africa.

Payne, J., Woodard, J. \& IRIS. , 2010. ICT to Enhance Farm Extension Services in Africa, in: USAID (Ed.), 
Briefing Paper, pp. 1-3.

Ritchie, B., Brindley, C., 2005. ICT adoption by SMEs: implications for relationships and management. New Technology, Work and Employment 20, 205217.

SNRD, 2018. Use of ICT for Agriculture in GIZ projects Status quo, opportunities and challenges of ICT. Sector Network Rural Development Africa, Accra, Africa.

Swanson, B.E., Rajalahti, R., 2010. Strengthening Agricultural Extension and Advisory Systems: Procedures for Assessing, Transforming, and Evaluating Extension Systems. , in: Washington, D.C.W.B. (Ed.), Agriculture and Rural Development Discussion Pape, p. 45.

Tadesse, T., 2010. Ethiopian Commodity Exchange (ECX)-Connecting farmers to the market. Swedish Business School, Orebro University, Sweden.

Tegegn, M., Dafisa, A., Prof, A., 2017. Review on Potential of Mobile Phone Usage in Agricultural Information Dissemination in Ethiopia. International Journal of Scientific and Research Publications 7, 63-75.

Thierfelder, C., Mombeyarara, T., Mango, N., Rusinamhodzi, L., 2013. Integration of conservation agriculture in smallholder farming systems of southern Africa: identification of key entry points. International Journal of Agricultural Sustainability 11, 317-330.

UNESCO, 2014. Education development as the top priority of the Organization - because education is a basic human right and the foundation for more sustainable, inclusive and just development. United Nations Educational, Scientific and Cultural Organisation, Paris, France.

Wondirad, A., 2015. Ethiopian Agricultural Hotline Surpasses 1 Million Caller Mark. Agri Pro Focus, London, GB.

World Bank, 2006. Improving smallholders' knowledge of agricultural practices and markets through innovative media platforms. World Bank, Washington, D.C.

World Bank, 2010. Improving smallholders' knowledge of agricultural practices and markets through innovative media platforms. World Bank, Washington, D.C.

World Bank, 2017. Improving smallholders' knowledge of agricultural practices and markets through innovative media platforms. World Bank, Washington, D.C.

Yared, M., 2015. Encapsulation of Case Studies on Mobile Applications that enhance Innovative Smallholderinclusive Agricultural Value Chain Finance.

Publisher's note: EScience Press remains neutral with regard to jurisdictional claims in published maps and institutional affiliations.

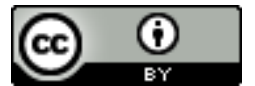

Open Access This article is licensed under a Creative Commons Attribution 4.0 International License, which permits use, sharing, adaptation, distribution and reproduction in any medium or format, as long as you give appropriate credit to the original author(s) and the source, provide a link to the Creative Commons license and indicate if changes were made. The images or other third-party material in this article are included in the article's Creative Commons license, unless indicated otherwise in a credit line to the material. If material is not included in the article's Creative Commons license and your intended use is not permitted by statutory regulation or exceeds the permitted use, you will need to obtain permission directly from the copyright holder. To view a copy of this license, visit http://creativecommons.org/licenses/by/4.0/. 